Nowoczesne Systemy Zarządzania

Zeszyt 12 (2017), nr 2 (kwiecień-czerwiec)

ISSN 1896-9380, s. 83-94

Modern Management Systems

Volume 12 (2017), No. 2 (April-June)

ISSN 1896-9380, pp. 83-94
Instytut Organizacji i Zarządzania

Wydział Cybernetyki

Wojskowa Akademia Techniczna

w Warszawie

Institute of Organization and Management

Faculty of Cybernetics

Military University of Technology

\title{
Przemówienia publiczne kadry kierowniczej wojsk lądowych jako element bezpieczeństwa kulturowego
}

\section{Public speeches of senior staff of the army as the safety component cultural}

\author{
Zbigniew Ciekanowski \\ Państwowa Wyższa Szkoła Techniczno-Ekonomiczna, \\ Instytut Ekonomii i Zarządzania \\ zbigniew@ciekanowski.pl
}

Abstrakt: W opracowaniu skupiono się na specyficznym aspekcie bezpieczeństwa kulturowego, który związany jest z przemówieniami publicznymi, traktowanymi jako element zarządzania kapitałem społecznym. Bazując na przeprowadzonych badaniach własnych oraz na krytycznej analizie literatury przedmiotu, wyciągnięto wnioski o zasadności zajmowania się wskazaną tematyką w środowisku kadry kierowniczej Wojsk Lądowych Sił Zbrojnych RP. Autor wskazuje na wagę transmisji postaw i wzorcotwórczej funkcji działalności oficera wobec dziedzictwa kulturowego, które zespolone z jednostką można rozpatrywać jako element kapitału ludzkiego.

Słowa kluczowe: bezpieczeństwo kulturowe, przemówienia publiczne, zarządzanie, kapitał społeczny.

Abstract: In contents of the study they concentrated on the peculiar safety aspect cultural which is connected with speeches public, treated as the element of managing the social capital. Being based on conducted own examinations and on the critical analysis of the literature on the subject, they concluded for legitimacies of doing recommended with subject matter in the environment of the senior staff of the army of military forces the Republic of Poland. The author shows transmission of attitudes by weight and models of function of activity of the officer towards the cultural legacy, which united with the individual it is possible to consider the element of the human capital.

Keywords: cultural safety, public speeches, management, social capital. 


\section{Wstęp}

We współczesnym rozumieniu bezpieczeństwa narodowego odchodzi się od koncepcji traktowania go tylko w wąskim militarnym ujęciu, związanym z niemożnością pokonania i dbaniem głównie o zdolności obronne. Powszechnie zaznacza się społeczny i kulturowy aspekt funkcjonowania narodu i zarówno w sferze legislacyjnej, jak i edukacyjnej, podkreśla się jego znaczenie. Zależnie od przyjętych klasyfikacji można spotkać bądź klarowne wyodrębnienie komponentu kulturowego, bądź traktowanie go jako element bezpieczeństwa społecznego. Niniejszy artykuł poświęcony został szczególnemu ujęciu bezpieczeństwa kulturowego, gdyż skupiono się w nim na aspekcie związanym z przemówieniami publicznymi, jako elementem zarządzania kapitałem społecznym. Treść artykułu w znacznej mierze oparto na badaniach własnych, przeprowadzonych w środowisku oficerów Wojska Polskiego. Uznano, że właśnie w tym obszarze świadomość przekazywanych treści i sposobu wpływania na odbiorców (żołnierzy i ludności cywilnej) podczas oficjalnych wypowiedzi okolicznościowych jest elementem godnym refleksji i naukowej analizy. Z uwagi na fakt, że profesja żołnierska znajduje się w czołówce zawodów, które obywatele traktują z pietyzmem i szacunkiem, zasadna wydaje się odpowiedź na pytanie: czy i w jakim stopniu jakość prezentacji osób publicznych w panteonie kadry oficerskiej jest zakresowo spójna z zagadnieniami bezpieczeństwa kulturowego? W niniejszym opracowaniu refleksji poddano zagadnienie transmisji kultury poprzez m.in. dawanie przykładu podwładnym, które traktowane jest jako szczególna forma kształtowania pożądanych postaw. Jest to metoda wiecznie aktualna, ponadto obecna w praktyce i literaturze przedmiotu od dawna. Odwołują się do niej eksperci z zarządzania, filozofii, dydaktyki itd.

\section{Bezpieczeństwo kulturowe a bezpieczeństwo narodowe}

Znawcy tematu podkreślają, że bezpieczeństwo (w ujęciu podmiotowym) służy zaspokojeniu potrzeb istnienia, przetrwania, rozwoju, poczucia niezależności, spokoju i posiadania itp. (Ciekanowski, Nowicka, 2016, s. 58). Jego istota bywa określana jako najwyższa egzystencjalna potrzeba i wartość narodowa (Jakubczak, Flis, 2006, s. 7). Celem państwa, według cytowanych autorów, jest „zapewnienie przetrwania, ochrony i obrony dziedzictwa narodowego, wartości i interesów narodowych przed istniejącymi i potencjalnymi zagrożeniami oraz tworzenie warunków pomyślnego życia i rozwoju obecnemu i przyszłemu pokoleniu Polaków" (Jakubczak, Flis, 2006, s. 7).

W literaturze przedmiotu bezpieczeństwo określane jest jako stan bądź proces wszelkiej aktywności dążącej do zachowania owego stanu, wreszcie jako stan i proces jednocześnie. Niewątpliwie trudności definicyjne związane są z pojemnością terminu 
„bezpieczeństwo” i z faktem, że określane jest ono zarówno przez obiektywne, jak i subiektywne czynniki. Należy mieć na uwadze, że bezpieczeństwo związane jest nie tylko $\mathrm{z}$ identyfikacją zastanego stanu, ale i $\mathrm{z}$ indywidualną oraz grupową interpretacją faktów, również tych wyobrażonych.

Szerokie postrzeganie zakresu pojęcia bezpieczeństwa sprawia, że konieczne staje się uwzględnianie nie tylko jego twardej militarnej strony, ale także jego miękkiego wymiaru uwzględniającego aspekty m.in.: ekologiczne, technologiczne, humanitarne, demograficzne czy kulturowe (Ciekanowski, 2016). Planowość i celowość działania w odniesieniu do kultury staje się nieodzownym ujęciem kategorii bezpieczeństwa i rozwoju lokalnego (Ciekanowski, 2016, s. 342).

Bezpieczeństwo kulturowe jest kategorią opisywaną przez ekspertów, choć nie zawsze wyszczególnianą w odrębnej klasyfikacji. Jego rozumienie, jako składowej bezpieczeństwa społecznego jest, zdaniem niektórych uczonych, wystarczającym akcentem i nie ma potrzeby nominalnego wyróżnienia. $Z$ uwagi na szeroki zakres terminu „bezpieczeństwo społeczne” - na potrzeby niniejszego opracowania, a i dla zachowania wewnętrznej spójności w refleksjach autorki tekstu - proponuje się wyodrębnienie kategorii bezpieczeństwo kulturowe i odniesienie się zwłaszcza do pewnego fragmentu jego zawartości. Nim jednak to nastąpi, warto zaznaczyć szczególną funkcję, jaką kultura pełni w narodzie. A. Kłoskowska opisuje kulturę narodową jako „szeroki i złożony układ sposobów działania, norm, wartości i symboli, wierzeń, wiedzy i dzieł symbolicznych, który przez jakąś zbiorowość społeczną uważany jest za własny, wyrosły z jej tradycji i historycznych doświadczeń oraz obowiązujący w jej obrębie" (Kłoskowska, 1991, s. 51). Kultura nadaje tożsamość i zakorzenia sens społecznego trwania. Przykłady historii kilka wieków wstecz pokazują, że kultura, więź narodowa i wyrosła na tym gruncie determinacja społeczna pozwoliły przetrwać państwu czas 123 lat rozbiorów i następnych XX-wiecznych krwawych walk o niepodległość. Obecnie „Rzeczpospolita Polska stwarza warunki upowszechniania i równego dostępu do dóbr kultury, będącej źródłem tożsamości narodu polskiego, jego trwania i rozwoju" (Konstytucja Rzeczypospolitej Polskiej art. 6). Wysiłek utrzymania tożsamości narodowej przejawia się między innymi w dbałości o język etniczny i wszelkie inne niematerialne i materialne dobra wytworzone przez społeczność danego narodu, w węższym rozumieniu - państwa. Można zatem za A. Dawidczykiem i J. Czputowiczem traktować bezpieczeństwo kulturowe jako „konieczność zapewnienia ochrony tożsamości narodowej, przeciwdziałanie zagrożeniom dla kultury (w związku z napływem obcych wartości z innych kręgów kulturowych), religii, języka" (Dawidczyk i in., 2001, s. 16).

Tadeusz Jemioło podkreśla rolę instytucji społecznych w kreowaniu bezpieczeństwa kulturowego, zaznaczając, że jest ono „zdolnością do pomnażania dotychczasowego dorobku kulturalnego oraz obrony przed niepożądanym wpływem innych kultur" (Jemioło, 2001, s. 20). 
Literatura przedmiotu oferuje wreszcie wiele definicji psychologicznych dotyczących kultury, które „odwołują się do mechanizmów psychicznych będących źródłem ludzkiej kreatywności, w tym procesu uczenia się, wytwarzania nawyków, zdolności komunikowania się i przejmowania wiedzy oraz umiejętności. Umiejętność posługiwania się symbolami i komunikowania się z innymi ludźmi stanowi istotny czynnik tworzenia i rozszerzania kultury, jej trwania w czasie i kumulacji dorobku kulturalnego" (Czajka, 2015, s. 9).

W jednym z dokumentów podpisanych przez Prezydenta Rzeczypospolitej Polskiej w listopadzie 2014 roku określono strategię bezpieczeństwa narodowego. Zaznaczono w niej potrzebę podjęcia działań społecznych umożliwiających rozwój duchowy i materialny obywateli naszego kraju. Aktywność społeczna wskazana jest w obszarze (Strategia Bezpieczeństwa Narodowego Rzeczypospolitej Polskiej 2014, s. 38-40, 52):

- ochrony i umacniania tożsamości narodowej;

- edukacji dla bezpieczeństwa;

- działalności mediów na rzecz bezpieczeństwa;

- przeciwdziałania zagrożeniom dla bezpieczeństwa demograficznego;

- zapewnienia bezpieczeństwa socjalnego.

Umacnianie tożsamości narodowej, w myśl przytaczanego dokumentu, realizowane jest m.in. poprzez pielęgnowanie dziedzictwa kultury narodowej oraz aktywizowanie kapitału społecznego, poprzez potęgowanie postaw patriotycznych i świadomego członkostwa w społeczności narodowej.

Polska jest jednym z dwóch krajów w Europie (obok Francji), które posiadają ochronę prawną dotyczącą używania języka ojczystego. Gwarantuje ją przyjęta w 1999 roku Ustawa o Języku Polskim. Na jej mocy uznano, iż „język stanowi podstawowy element narodowej tożsamości i jest dobrem narodowej kultury" (Ustawa z dnia 7 października 1999 r. o języku polskim, nr 84, poz. 455).

\section{Przemówienia publiczne jako językowy i pozajęzykowy element dobra narodowego}

Władanie słowem jest immanentną cechą człowieka i wpływa na zasób dóbr tworzących kapitał ludzki. Jest on rozumiany jako „umiejętność tworzenia nowych wartości, przede wszystkim: wiedzy, umiejętności, zdrowia, energii witalnej, kultury czy tradycji" (Marciniak, 2002, s. 12-13).

Skoro język jest dobrem narodowym i determinuje poczucie tożsamości narodowej, kwestię operowania nim, i porozumiewania się w ogóle, zasadne jest traktować jako dbałość o fragment bezpieczeństwa kulturowego państwa. Zwłaszcza w odniesieniu do osób zajmujących stanowiska w administracji państwowej i instytucjach finansowanych z budżetu państwa, powyższa teza wydaje się społecznie zasadna. 
Aktywność osoby przemawiającej przed audytorium w znacznej części opracowań teoretycznych rozpatrywana jest $\mathrm{w}$ dwóch wymiarach: werbalnym i niewerbalnym. Wydaje się jednak, że ów dychotomiczny podział jest zawężeniem tematu, skutkującym niedopracowaniem, a często $\mathrm{w}$ ogóle pominięciem sfery parajęzykowej wypowiedzi. Rozważania na ten temat nie są istotą niniejszego artykułu, jednak wydają się niezbędnym wstępem do zrozumienia zasadności trzystopniowego podziału aktywności mówcy. Rekomenduje się zatem, by aspekty prezentacji publicznej dzielić na:

- językowy - związany z werbalizmem, użyciem kodu językowego w celu nawiązania porozumienia;

- parajęzykowy - związany z impostacją głosu, akcentem, tempem mowy, iloczasem, embolofrazją itp.;

- pozajęzykowy - związany z dynamiką ruchu, strojem, zachowaniem, proksemiką, kodem niewerbalnym - pozbawionym elementów parajęzykowych.

W ostatnim dziesięcioleciu coraz wyraźniej podnosi się kwestę potrzeby kształcenia kompetencji społecznych, komunikacyjnych, dowódczych, przywódczych. Jednak odnoszenie się do prezentacji publicznej oficera i jego umiejętności komunikacyjnych jest wciąż głosem wielce skromnym. Interesujący, choć w świetle badań (Majewski, 2006) dyskusyjny, jest fakt nazywania języka w wojsku artefaktem kultury organizacyjnej (Łydka, 2015, s. 102-103), czyli zwrotami słownymi charakterystycznymi dla tejże instytucji. Wydaje się bowiem, że przy okazji przemówień okolicznościowych, zwłaszcza tych obejmujących audytorium wojskowe i cywilne, wskazane jest posługiwanie się normą ogólnopolską, i to normą wzorcową. Dzieje się tak w odniesieniu do faktu, że nadrzędną rolą żołnierza jest dbanie o bezpieczeństwo, również to kulturowe. Na mocy ustawy o języku polskim należy je traktować jako wartość wymagającą stałej praktyki doskonalenia wśród wszystkich obywateli (żołnierzy również). I słowa te nie odnoszą się tylko do kwestii nadużywania wulgaryzmów, ale do kultury użycia języka w ogóle. „Poprawność językowa (...), elokwencja oraz stosowna terminologia wojskowa wpływają na postrzeganie poszczególnych oficerów" (Łydka, 2015, s. 102-103). Dostrzeganie potrzeby dbałości o jakość używanego języka i formy komunikacji w armii nie jest wcale wymysłem współczesnych czasów i mody. Opisując zamierzchłe czasy Wojska Polskiego, Tadeusz Hołówko wskazuje, że „oficer jest to obywatel wrażliwy na wszystkie przejawy życia swojego narodu, (...) będący dla żołnierza starszym, troskliwym bratem, a nie nadzorcą (...), mądrem słowem i dobrym przykładem, a nie pięścią zniewalający do posłuchu" (Hołówko, 1996, s. 24).

Kolejnym przykładem niech będą słowa Marszałka Józefa Piłsudskiego, który organizując werbunek w 1914 r., odniósł wynik wielokrotnie lepszy niż ówcześnie działające Centralne Biuro Werbunkowe Departamentu Wojskowego. Aranżując swoją akcję, Marszałek, pisał m.in. „Jestem też przekonany, że nie należy zapominać o dodatkowych rzeczach zewnętrznych, jak muzyka, zebrania towarzyskie, obchody 
i uroczystości wojskowe, które mogą wywrzeć głęboki wpływ na ludność i przyczynić się do spopularyzowania idei wojskowej" (Gajdziński, 2013, s. 104).

Wydaje się więc, że w środowisku wojskowym w pełni uświadomiona jest teza, iż dobra prezentacja przynosi wydźwięk nie tylko jednostkowy, lecz także społeczny. „To możliwość zbudowania własnej reputacji - jako myśliciela, jako kogoś, kto wie, o czym mówi czy jako człowieka czynu, który powoduje, że coś zostanie zrobione" (Abramowicz, 2000, s. 129). Świadomość wpływania na odbiorców poprzez jakość i ilość swoich wypowiedzi publicznych nabiera znaczenia wobec zapisu Strategii Bezpieczeństwa Narodowego traktującego o szerokim współdziałaniu administracji publicznej z mediami, czego przejawem mogą być wystąpienia przed kamerą, tworzenie informacji prasowych, komentowanie zaistniałych zdarzeń w massmediach. Ujawnia się wtedy transsektorowość i uniwersalność zasad porozumiewania się i autoprezentacji publicznej.

\section{Oficer jako elita}

Pojawia się pytanie, w jaki sposób oficer może realizować postulat Strategii Bezpieczeństwa Narodowego, by promować obszary tradycji i dziedzictwa kulturowego? (Strategia Bezpieczeństwa Narodowego Rzeczypospolitej Polskiej 2014, s. 52). Odpowiedzią mogą być m.in. wyniki badań światowych naukowców. „W ciągu ostatnich trzydziestu lat (...) dawanie przykładu jest jedną z najpotężniejszych metod wpływania na cudze zachowanie. Mówiąc najprościej, ludzie często naśladują zachowanie, które widzą u innych" (Leary, 2005, s. 170).

\subsection{Potrzeba kształcenia kompetencji komunikacyjnych}

Dzisiejszy system kształcenia wojskowego, chociażby ze względu na zmieniający się charakter prowadzonych operacji wojskowych, winien finalnie dostarczać armii mądrych dowódców, dla których oczywistością będzie łączenie sztuki wojskowej z ogólnie humanistycznym podejściem do człowieka. Istotą jest kształcenie dowódców, którzy będą mieli przeświadczenie o wyższości budowania swojego autorytetu poprzez posiadane kompetencje komunikacyjne, a nie tylko zdyscyplinowanie wypływające $\mathrm{z}$ uprawnień formalnych. Jak wykazały przeprowadzone badania, oficerowie Wojsk Lądowych, nawet ci o wrodzonych talentach liderskich, potrzebują realnej pomocy $\mathrm{w}$ nabywaniu kompetencji komunikacyjnych przydatnych m.in. w odniesieniu do przemówień publicznych (Badania przeprowadzono na przełomie 2015-2016 r., na reprezentatywnej próbie 396 oficerów Wojsk Lądowych Akademii Obrony Narodowej). Przytoczone badania pokazują, iż od przełożonego oczekuje się profesjonalnych zachowań oratorskich, zaś od placówek kształcenia wojskowego, by zatrudniały ekspertów o wysokim poziomie prezentowanych kompetencji progowych, komunikacyjnych 
i wyróżniających (emocjonalnych). Wskazanie właśnie tej triady, zdaniem badanych, umożliwia zbudowanie autorytetu wśród podwładnych, jednocześnie uprawomocniając ich do kształcenia innych, budowania relacji z nimi i wyposażania ich w narzędzia umożliwiające funkcjonowanie intelektualne, zawodowe i społeczne.

Nawet jeśli oratorstwo nie przesądza o karierze w strukturze wojska (czy np. polityki), to z pewnością odgrywa istotną rolę w kształtowaniu wizerunku i skupianiu stronników. Liczne badania dowodzą (Kliber, Barker, 1972; Klinger, 1959; Utzinger, 1952), (Knapp, Hall, 2000, s. 514), że niedopracowanie parajęzykowych walorów wypowiedzi może skutkować negatywnym odbiorem mówcy, kojarzonym z jego rysem osobowościowym.

Oficer, wydaje się, ma historycznie wpisany duch umiłowania do kraju, któremu służy, trudno krzewić tę miłość, nie korzystając z dobroci i poprawności słowa, którym społeczność narodowa się posługuje. „Oficer przede wszystkim będzie organizatorem i pedagogiem, aby zaś te zadania mógł należycie spełniać, winien być człowiekiem idei i powołania o wysokiej kulturze duchowej i rozległej wiedzy (...)" (Hołówko, 1996, s. 24). Dochodzimy w swych rozważaniach do momentu, gdy przełożony jawi się jako wzorzec, stymulujący proces transmisji kultury.

\subsection{Transmisja kultury determinantem bezpieczeństwa kulturowego}

Fakt, że oficer jest źródłem wiedzy, obiektem naśladowanym, promującym kontynuowanie swej postawy u podwładnych, aktywuje transfer umożliwiający funkcjonowanie tradycji. Cechę tę należy ujmować w kategoriach pozytywnych. Postęp kultury, w sensie jej trwania w pokoleniach, możliwy jest poprzez wpływ mistrza na ucznia (Pieter, 1967, s. 290-296).

„Kultura w węższym znaczeniu oznacza całokształt wytworów i zachowań opartych na systemach symbolicznych i odpowiadających im konwencjach regulujących aktywność ludzi. Spełnia ona funkcję kodowania, przechowywania i przekazywania doświadczenia ludzi żyjących w kręgu danej kultury" (Przetacznik-Gierowska, Tyszkowa, 2009, s. 106).

W myśl traktowania norm jako rodzaju przewodnika i drogowskazu postępowania (Sherif, 1936), (Brown, 2006, s. 64) normy zachowań oracyjnych oficerów stanowią swoistą ramę odniesienia pomagającą interpretować świat i zachowania pożądane wśród podległej kadry żołnierskiej. Oficerowie świadomie wraz ze złożonym ślubowaniem zdecydowali się być ogniwem w procesie modelowania. Biorą zatem na siebie odpowiedzialność związaną z odgrywaniem „roli wzoru do naśladowania lub wywierania wpływu na innych poprzez aktywne nauczanie, szkolenie, bądź udzielanie wskazówek" (Bacon, 2013, s. 181). Stają się inspiracją dla podwładnych, także w zagadnieniach zachowań społecznych i językowych. „Działania jednostki nie wyznaczają obiektywne czynniki, ale jej miejsce w świadomości członków grupy, sposób jej widzenia i traktowania" (Wasilewski, Skibiński, 2008, s. 82). 
Funkcja oficera, postrzeganego jako źródło wiedzy i obyczaju, ma jednak i wskazanie wadliwe. Dotyczy ono sytuacji, gdy podmiot nie dba należycie o jakość postaw, które przekazuje, także w sferze werbalnej (Nowicka, 2016, s. 115). Podobnie, jeśli przemawiając publicznie, używa przewidywalnych i nużących figur retorycznych, przekazuje słuchaczom wzór pozbawiony oryginalnych rozwiązań, zatem nie rozbudza kompetencji komunikacyjnych, ani nie pobudza komunikacyjnego wywierania wpływu. Jak wskazuje Model Oficera Mówcy, cytowane słabości nie są tworem czysto teoretycznym, ale mają swoje odzwierciedlenie w praktyce oratorskiej współczesnej kadry kierowniczej Wojsk Lądowych (Nowicka, 2016, s. 152-156).

Powstaje dylemat, jak pogodzić hierarchiczny rys instytucji wojska z retoryczną potrzebą podkreślania indywidualności mówcy i potrzebnej liderskiej umiejętności przełamywania rutyny w celu budowania zainteresowania. Jest to niewątpliwie wyzwanie i trud, któremu niewielu potrafi sprostać. Podporządkowanie się sugestii przełożonego jest w instytucji wojska kwestią podstawową. Nawet w zakresie przemówień publicznych odejście od podpowiedzi zwierzchnika uznane może zostać za przejaw „zachowania anarchistycznego. Za takie J.M. Bocheński uznaje ustrój, albo raczej rozstrój - w którym nie ma żadnego przymusu, a więc i autorytetu deontycznego sankcji” (Bocheński, 1994, s. 17), co zaprzecza idei hierarchicznej instytucji wojska.

Postrzeganie potencjalnego przywódcy, a za takiego chciałoby się uznawać każdego oficera RP, może być wynikiem odbierania go przez określony pryzmat. „Wrażenie, które odbierają inni, częściowo decyduje o tym, kto może zdobyć i utrzymać rolę przywódcy. Dla osoby, która chce zająć takie miejsce, umiejętność budowania wizerunku odpowiedniego do roli lidera jest niezmiernie ważna" (Leary, 1989, s. 97). W środowisku wojskowym, pełnym obostrzeń związanych z pełnioną funkcją, posiadanym stopniem, ceremoniałem, wreszcie silną kulturą organizacyjną, bycie mówcą skutecznym nie jest kwestią prostą i oczywistą.

Fakt uczestniczenia Polski w strukturach sojuszniczych i koalicyjnych wymaga od żołnierzy otwarcia się na nowoczesne zarządzanie oparte na wartości komunikacji i współdziałaniu. Prawa porozumiewania się, budowania swego wizerunku słowem i postawą, są wartościami uniwersalnymi, niezależnie od języka, którym się operuje. Umiejętność korzystania z dóbr komunikacji parawerbalnej, modulowania głosem, intonacją, używanie figur retorycznych i znajomość mowy ciała są niezbędnymi narzędziami współczesnego oficera i wymagają przystosowania się do standardów światowych, które doceniają rolę nauki komunikacji. Często standardy mów publicznych w środowisku wojskowym, będące pozostałością minionego systemu, nie są adekwatne do rzeczywistości, ponieważ opierają się na autorytecie deontycznym. „Elastyczność, adaptacyjność i tolerancyjność nie są czymś wspólnym w autokratycznym środowisku, jakie było w czasach PRL, istnieje potrzeba nabycia kompletu nowych umiejętności, aby przetrwać w przyszłości psychicznie" (Abramowicz, 2000, s. 135; Leary, 2005, s. 86). 
Oficer powinien dbać o spójność wizerunku i wymowy utrzymanej na danym poziomie poprawności zarówno podczas oficjalnych spotkań, jak i podczas codziennego funkcjonowania społecznego.

Niezależnie od tego, jak zmienia się typ oficera polskiego, winien on w każdym momencie „czcić święcie pamięć swoich poprzedników, mniej od niego szczęśliwych, iść w ich ślady i tak jak oni, być uosobieniem cnoty żołnierskiej, ducha obywatelskiego, bojownikiem o postęp i nowe światłe idee" (Hołówko, 1996, s. 74).

\section{Podsumowanie}

$\mathrm{Na}$ elementy dziedzictwa kulturowego zespolone $\mathrm{z}$ jednostką zasadnie jest patrzeć jak na element kapitału ludzkiego, który jest w pewnym sensie uwarunkowany genetycznie, ale może wzrastać poprzez inwestycję w osobę (Domański, 1993, s. 35). Jego związek z bezpieczeństwem narodowym przejawia się nie tylko w pielęgnowaniu tożsamości, lecz także może być przydatny w codziennym funkcjonowaniu stanowiącym rozwój jednostek i społeczeństwa. Czerpiąc bowiem z nauk ekonomicznych, można przyjąć, iż „kapitał ludzki jest to zespół zdolności fizycznych, a także psychicznych i intelektualnych jednostki, które mogą być używane w życiu gospodarczym" (Domański, 1993, s. 35).

Rodzi się pytanie: czy mowa i szeroko rozumiana kultura są w wojsku tylko zbędną rozrywką, czy może noszą charakter funkcjonalności? Analiza literatury przedmiotu wskazuje, że elementy wskazane powyżej doceniane są przez wodzów dawnej i współczesnej Polski. „Żadna grupa zawodowa nie może wskazać na trwałość jej legitymizacji w oczach społeczeństwa, o nią trzeba stale zabiegać, wzmacniać, utrwalać" (Sasińska-Klas, 2016 s. 140). Czynić to można między innymi poprzez starania o jakość postrzegania i kulturę komunikowania się. Budować więzi i kapitał społeczny, które są niezbędne przy działaniach grupowych, można tylko w oparciu o docenienie społecznych aspektów funkcjonowania człowieka, a te zawsze powstają w nawiązaniu do szeroko rozumianej umiejętności komunikowania się, zarówno na poziomie językowym, parajęzykowym, jak i pozajęzykowym.

Inspiracją powstania niniejszego tekstu było zwrócenie uwagi na wagę kompetencji tzw. miękkich, które często bywają traktowane tylko jako kosmetyka i oczywistość niewarta systematycznego zgłębiania i rozwijania w sposób planowy. Punktem wyjściowym do wskazanego działania zorganizowanego jest - zdaniem autorki tych słów - autorefleksja. Samoświadomość traktowana jako „dyspozycja, która sprawia, że posiadający ją człowiek nadaje sobie praktycznie, to jest nie tylko w teorii, ile i w czynie taką właśnie wartość, jaką posiada" (Bocheński, 1993, s. 77). Można za Bocheńskim nazwać ową dyspozycję pokorą lub skromnością. Istotą jest zakorzenienie jej w samoświadomości, którą należy rozwijać w procesie kształcenia. 
Jednym ze sposobów pojmowania elity jest jej ujęcie w kontraście do masy, czyli tej części społeczeństwa, która się niczym nie wyróżnia (Bocheński, 1993, s. 75). Elita stanowi grupę odniesienia i nadaje jej ten fakt charakter misyjny. Stąd, prezentowany przez kadrę kierowniczą w wojsku system aksjonormatywny winien stanowić pozytywną grupę odniesienia. Oficer będąc wzorem do naśladowania, pokazuje pożądane postawy, kształtując w ten sposób patriotyczne oblicze podwładnego i świadomie bądź nie, wzmacnia określoną kulturę organizacyjną. Zapewnianie trwałości tradycji i krzewienie idei bezpieczeństwa kulturowego wzmacniane są m.in. poprzez odpowiednie rytuały. Można przez nie rozumieć „powtarzane sekwencje działań, wyrażające i wzmacniające podstawowe wartości organizacji, wskazujące na to, które cele są ważne i którzy ludzie są potrzebni lub zbędni” (Robbins, 2004, s. 443). Transmisja dziedzictwa kulturowego może odbywać się wielotorowo. Jednym $\mathrm{z}$ wariantów jest wywieranie wpływu poprzez autoprezentację, silnie opartą o wartość werbalną, która stanowi element etosu oficera.

\section{BIBLIOGRAFIA}

[1] Bacon T.R., 2013, Sposób na opornych. Skuteczne wywieranie wpływu, GWP, Sopot.

[2] BąK T., CieKanowski Z. (red.), 2016, Bezpieczeństwo państwa w warunkach globalizacji, PWST-E, Jarosław.

[3] Bąк T., Ciekanowski Z., Nowicka J. (red.), 2016, Wspótczesne zagrożenia bezpieczeństwa państwa, PWST-E, Jarosław.

[4] Bocheński J.M., 1993, De Virtute Militari. Zarys etyki wojskowej, Philed, Kraków.

[5] Bocheńsкi J.M., 1994, Sto zabobonów. Krótki filozoficzny słownik zabobonów, Philed, Kraków.

[6] Brown R., 2006, Procesy grupowe - dynamika wewnątrzgrupowa i międzygrupowa, GWP, Gdańsk.

[7] Czaja J., 2008, Kulturowe czynniki bezpieczeństwa, Krakowskie Towarzystwo Edukacyjne, Kraków.

[8] DAwıdсzyк A., 2001, Nowe wyzwania, zagrożenia i szanse dla bezpieczeństwa Polski u progu XXI wieku, Akademia Obrony Narodowej, Warszawa.

[9] Dęвski S., B. Górka-Winter (red.), 2003, Kryteria bezpieczeństwa międzynarodowego państwa, PISM, Warszawa.

[10] Domański S.R., 1993, Kapitał ludzki i wzrost gospodarczy, PWN, Warszawa.

[11] Drzycimski A., 2000, Komunikatorzy, wplyw, wrażenie, wizerunek, Oficyna Wydawnicza Branta, Warszawa-Bydgoszcz.

[12] Gajdziński P., 2013, Sztuka przywództwa. Piłsudski, Wydawnictwo Poznańskie.

[13] Ноєówко T., 1996, Oficer polski, Wyd. Czasopisma Wojskowe, Warszawa.

[14] JakubczaK, J. Flis (red.), 2006, Bezpieczeństwo Narodowe Polski w XXI wieku. Wyzwania i strategie, Bellona, Warszawa.

[15] Jеміоєо T., 2001, Bezpieczeństwo kulturowe w warunkach globalizacji i procesów społecznych, [w:] Kultura narodowa w kształtowaniu świadomości obronnej społeczeństwa i bezpieczeństwa państwa, „Zeszyt Problemowy TWO”, nr 3/25.

[16] KŁosкowsкa A. (red.), 1991, Encyklopedia kultury polskiej XX wieku, Wyd. Uniwersytetu Wrocławskiego, Wrocław.

[17] Knapp M.L., Hall J.A., 2000, Komunikacja niewerbalna w interakcjach międzyludzkich, Astrum, Wrocław. 
[18] Kompetencje społeczne kadry dowódczej WP w kontekście realizacji zadań służbowych, 2014, Sprawozdanie badań, WBBS, Warszawa.

[19] Konstytucja Rzeczypospolitej Polskiej.

[20] LeARy M., 2005, Wywieranie wrażenia na innych, GWP, Gdańsk.

[21] Łydka W., 2015, Doskonalenie kompetencji przywódczych oficerów, Akademia Obrony Narodowej, Warszawa.

[22] Majewski T., 2006, Kompetencje dowódcze oficerów wojsk lądowych Sił Zbrojnych RP, Akademia Obrony Narodowej, Warszawa.

[23] Marciniak S. (red.), 2002, Perspektywy kapitału ludzkiego jako czynnika wzrostu gospodarczego Polski, Politechnika Warszawska, Kolegium Nauk Społecznych i Administracji, Warszawa.

[24] Nowicka J., 2016, Kompetencje komunikacyjne kadry kierowniczej Wojsk Lądowych, AON, Warszawa.

[25] Nowicka J., 2016, Rola oficera w komunikacji społecznej, Zeszyty Naukowe Wojskowa Akademia Techniczna, Warszawa.

[26] Pieter J., 1967, Ogólna metodologia pracy naukowej, Zakład Narodowy im. Ossolińskich, Wrocław.

[27] Przetacznik-Gierowska M., Tyszkowa M., 2009, Psychologia rozwoju człowieka, tom 1, PWN, Warszawa.

[28] Roвbins S.P., 2004, Zachowania w organizacji, tłum. A. Ehrlich, Polskie Wydawnictwo Ekonomiczne, Warszawa.

[29] Strategia Bezpieczeństwa Narodowego Rzeczypospolitej Polskiej, 2014.

[30] Ustawa z dnia 7 października 1999 r. o języku polskim (tekst jedn.: Dz. U. z 2011 r. Nr 43, poz. 224 z późn. zm.), Nr 84, poz. 455.

[31] Wasilewski J., Skibiński A., 2008, Prowadzeni słowami. Retoryka motywacji w komunikacji publicznej, Difin, Warszawa.

\section{NETOGRAFIA}

[1] Ciekanowski Z., Działania asymetryczne jako źródło zagrożeń bezpieczeństwa, http://yadda. icm.edu.pl/yadda/element/bwmeta1.element.baztech-article-BGPK-3205-2380/c/httpwww_bg_ utp_edu_plartbtp2032009ciekanowski.pdf.

[2] Czaja J., Bezpieczeństwo kulturowe Rzeczpospolitej Polskiej, http://adamkorcz.w.interia.pl/ kultur. pdf. 
